\title{
Non-Canonical Effects of ACTH: Insights Into Adrenal Insufficiency
}

\author{
Valeria Hasenmajer, Ilaria Bonaventura, Marianna Minnetti, Valentina Sada, \\ Emilia Sbardella and Andrea M. Isidori ${ }^{*}$ \\ Department of Experimental Medicine, Sapienza University of Rome - Policlinico Umberto I Hospital, Rome, Italy
}

\section{OPEN ACCESS}

Edited by:

Alberto Falorni,

University of Perugia, Italy

Reviewed by:

Cristina L. Ronchi,

University of Birmingham,

United Kingdom

Roberta Giordano,

University of Turin, Italy

Biswadeep Das,

KIIT University, India

*Correspondence:

Andrea M. Isidori

andrea.isidori@uniroma1.it

Specialty section: This article was submitted to Translational Endocrinology,

a section of the journal

Frontiers in Endocrinology

Received: 27 April 2021 Accepted: 04 August 2021

Published: 19 August 2021

Citation:

Hasenmajer V, Bonaventura I, Minnetti M, Sada V, Sbardella E and Isidori AM (2021) Non-Canonical

Effects of ACTH: Insights Into Adrenal Insufficiency.

Front. Endocrinol. 12:701263. doi: 10.3389/fendo.2021.701263
Introduction: Adrenocorticotropic hormone $(\mathrm{ACTH})$ is produced from proopiomelanocortin, which is predominantly synthetized in the corticotroph and melanotroph cells of the anterior and intermediate lobes of the pituitary gland and the arcuate nucleus of the hypothalamus. Although ACTH clearly has an effect on adrenal homeostasis and maintenance of steroid hormone production, it also has extra-adrenal effects that require further elucidation.

Methods: We comprehensively reviewed English language articles, regardless of whether they reported the presence or absence of adrenal and extra-adrenal ACTH effects.

Results: In the present review, we provide an overview on the current knowledge on adrenal and extra-adrenal effects of ACTH. In the section on adrenal ACTH effects, we focused on corticosteroid rhythmicity and effects on steroidogenesis, mineralocorticoids and adrenal growth. In the section on extra-adrenal effects, we have analyzed the effects of ACTH on the osteoarticular and reproductive systems, adipocytes, immune system, brain and skin. Finally, we focused on adrenal insufficiency.

Conclusions: The role of ACTH in maintaining the function of the hypothalamic-pituitaryadrenal axis is well known. Conversely, if we broaden our vision and analyze its role as a potential treatment strategy in other conditions, it will be evident in the literature that researchers seem to have abandoned this aspect in studies conducted several years ago. We believe it is worth re-evaluating the role of ACTH considering its noncanonical effects on the adrenal gland itself and on extra-adrenal organs and tissues; however, this would not have been possible without the recent advances in the pertinent technologies.

Keywords: adrenal gland, adrenocorticotropic hormone, adrenal insufficiency, proopiomelanocortin, adrenal diseases, ACTH, POMC, extra-adrenal effects

\section{INTRODUCTION}

Adrenocorticotropic hormone (ACTH) was first described in 1933, and after nearly 20 years, it was demonstrated that this polypeptide hormone stimulates adrenocortical activity (1-3). ACTH is exclusively produced from prohormone proopiomelanocortin (POMC), which is majorly synthetized in the corticotroph and melanotroph cells of the anterior and intermediate lobes of the pituitary gland and the arcuate nucleus of the hypothalamus. ACTH synthesis has also been described in other organs, such as the skin (4). After synthesis and folding, POMC is transported in vesicles and processed in secretory granules before ultimately reaching the plasma membrane (5). 
The selective cleavage of POMC by prohormone convertase (PC) and the timing of secretion are cell-specific and follow the regulated secretory pathway, along with other hormones (6) because of a highly conserved sorting signal motif (7). In immature secretory granules, $\mathrm{PC} 1 / 3$ and PC2 enzymes process POMC. In the anterior pituitary lobe, $\mathrm{PC} 1 / 3$ is responsible for the posttranslational cleavage that generates $16-\mathrm{kDa} \mathrm{N}-\mathrm{POMC}$, $\mathrm{ACTH}$, and $\beta$-lipotropin. In the intermediate pituitary lobe and hypothalamus, a more complex processing of POMC, including PC2 activity along with other enzymes, generates more active peptides, such as $\alpha$-melanocyte-stimulating hormone and $\beta$ endorphin (8).

After its cleavage from POMC by PC1/3, ACTH is secreted by mature granules from the anterior lobe of the pituitary gland into the circulation, targeting its receptor on peripheral cells, the melanocortin 2 receptor (MC2R). In addition to MC2R, which is highly specific for ACTH, other melanocortin receptors (MCRs; MCR1, MCR3, MCR4, and MCR5) can bind to ACTH and other POMC-derived peptides. These receptors are expressed in various tissues (Table 1). MC2R is part of the melanocortin receptor family, a group of class A G-protein-coupled receptors (GPCRs) that share binding to melanocyte-stimulating hormone peptides (9) and are the smallest GPCRs known. In contrast to other MCRs, MC2R binding requires melanocortin-2 receptor accessory protein 1 (MRAP) for proper migration to plasma membrane and receptor-ligand complex formation and downstream signaling (10). The function of MRAP is crucial to ACTH function, and mutations in its gene cause ACTH resistance syndrome and type 2 familial glucocorticoid deficiency (10).

Similar to other GPCRs, MC2R activation leads to an increase in intracellular cyclic adenosine monophosphate (cAMP) stimulating the protein kinase A (PKA) signaling pathway (11). Other intracellular pathways activated by ACTH are mitogen-activated protein kinase (12) and cAMP response element-binding protein (13). A role of calcium influx that cooperates with ACTH-mediated steroid synthesis has also been identified, and many other secondary messengers are involved in ACTH downstream signaling, although their independence from the PKA pathway is still under discussion (14). The interaction between MC2R and ACTH in the adrenal glands leads to transcription of genes responsible for steroidogenesis, such as the steroidogenic acute regulatory protein (StAR) (14).

Aim of this review is to provide an overview of the effects of $\mathrm{ACTH}$, focusing on the impact of extra-adrenal and noncanonical signaling in health and disease. First, we will briefly summarize evidence on the impact of ACTH signaling on glucocorticoid, mineralocorticoid and androgen secretion, the role in mediating adrenal growth and development and the effects on steroidogenesis and gene expression. Then, we will describe the effects of ACTH on the osteoarticular and reproductive systems, adipocytes, immune system, brain and skin (Figure 1). Lastly, we will provide an overview of the role of ACTH in adrenal disorders, focusing on adrenal insufficiency and suggesting possible implications of its excess and defect.

We performed a research of published literature with no time constraints. Only English papers were included. When possible, results from human studies were preferred over in vitro or animal studies. Being out of the main scope of this review, papers focusing on ACTH as a diagnostic marker for adrenal diseases were excluded.

\section{ADRENAL EFFECTS OF ACTH}

\section{Corticosteroid Rhythmicity}

It is well established that circadian changes in ACTH and glucocorticoids are associated with expression of clock-related genes (15-19). In adrenal tumors, the clock machinery that mitigates the response to ACTH and stress favors a higher and more arrhythmic corticosteroid secretion when dysregulated, suggesting that hypercortisolism exerts effects on circadian genes, contributing to the worsening of disease-related comorbidities $(16,20,21)$. Circadian gene expression is dysregulated in patients with adrenal insufficiency and normalize under more physiological timing of glucocorticoids, emphasizing the importance of synchronization of clocks to coordinate the endogenous and exogenous signals to achieve cellular homeostasis $(22,23)$.

\section{Effects on Steroidogenesis}

$\mathrm{ACTH}$ is the key hormone controlling steroidogenesis in the adrenal gland, inducing responses in both the short and long terms. Acute and chronic ACTH stimulation lead to the mobilization of cholesterol, the first substrate for steroidogenic pathway (24), owing to the increase in StAR gene transcription (25, 26). StAR catalyzes the conversion of cholesterol to pregnenolone, the first and limiting step of steroidogenesis. Other steroidogenic enzymes, such as P450scc, the mitochondrial cholesterol side-chain cleavage enzyme that catalyzes conversion of cholesterol to pregnenolone, and P450C11 (11beta-hydroxylase), which catalyzes the transformation of deoxycorticosterone to

TABLE 1 | Melanocortin receptors (MCRs) and main sites of expression.

\begin{tabular}{|c|c|}
\hline Receptor & Tissues \\
\hline MC1R & Melanocytes and immune cells \\
\hline MC2R & Adrenal cortex, adipocytes, testis, prostate, endometrium, and immune cells \\
\hline MC3R & Hypothalamus, limbic system, immune cells, placenta, gut, and kidney \\
\hline MC4R & Hypothalamus, limbic system, brain, spinal cord, and immune cells \\
\hline MC5R & Muscles, liver, spleen, lungs, brain, and adipocytes \\
\hline
\end{tabular}




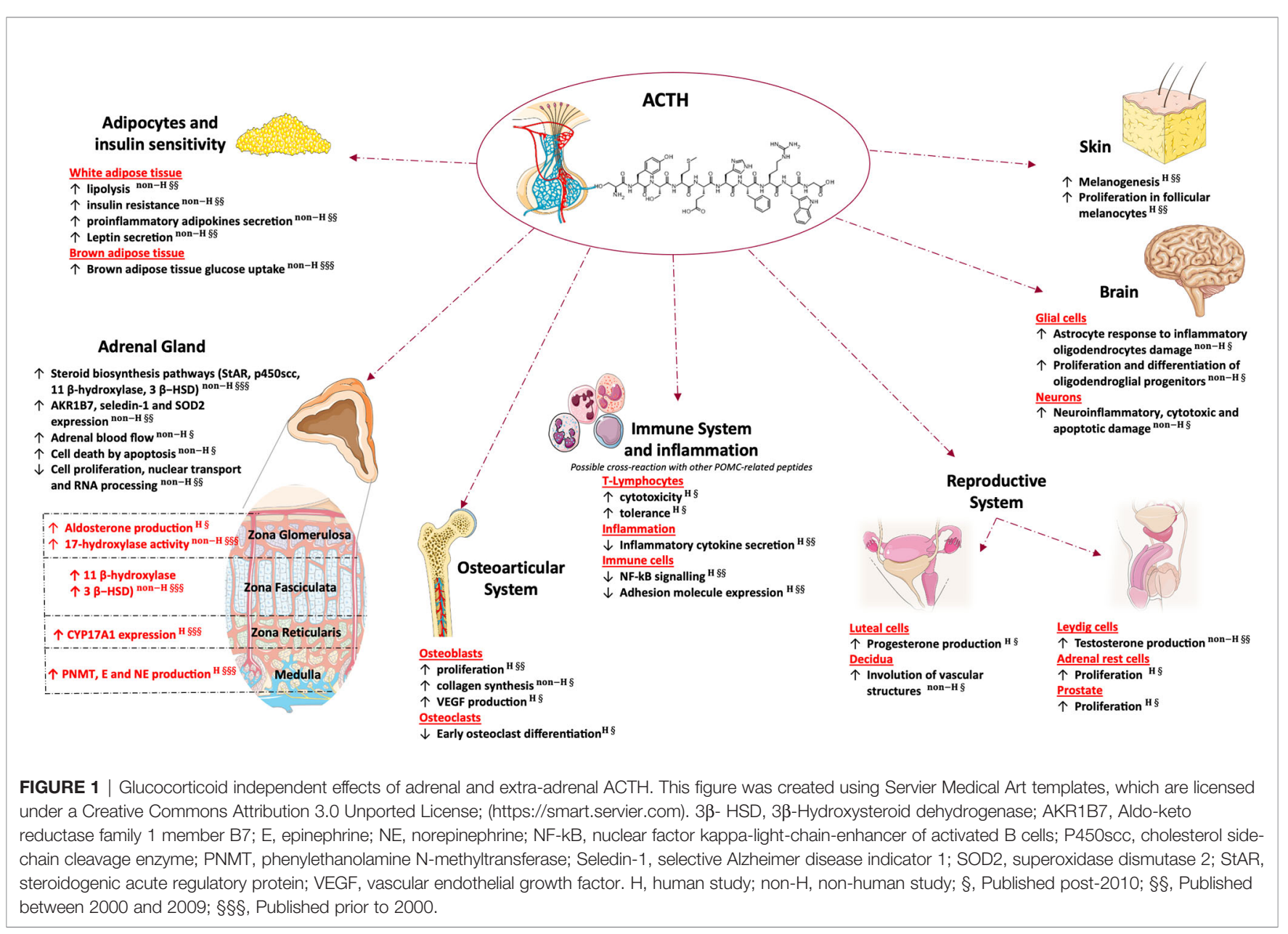

corticosterone and that of 11-deoxycortisol to cortisol (25), are responsive to chronic ACTH stimulation. Through CYP17A1, ACTH promotes the secretion of androgen precursors, dehydroepiandrosterone (DHEA), its sulphated derivative DHEAS and androstenedione (27). Furthermore, an increase in size of the adrenal gland occurs after chronic ACTH administration, suggesting that this hypertrophy is a consequence of steroidogenesis enhancement (28). Under physiological conditions, ACTH mainly controls cortisol and androgen precursors secretion, even though the concept that aldosterone production is independent of ACTH is now outdated. As ACTH binding to MC2R also stimulates aldosterone secretion in addition to cortisol, even doses of ACTH within the physiological range can induce aldosterone synthesis (29-32) through a slow, but sustained, $\mathrm{Ca}^{2+}$ influx (33). In fact, ACTH binding to MC2R results in the production of second messengers (cAMP together with $\mathrm{Ca}^{2+}$ influx). This pathway, through positive feedback loops, enhances steroid secretion (14). Different exposures to ACTH might affect aldosterone production differently; in fact, under continuous intravenous ACTH infusion aldosterone increases and then returns to basal levels within 72 hours, but pulsatile administration of ACTH, which mimics its physiological release, causes aldosterone to remain at high levels (34). However, most results on strong aldosterone stimulation by
ACTH are limited to in vitro studies (14) while evidence from animal models suggest an inhibitory effect of Angiotensin II signaling on cAMP and $\mathrm{Ca}^{2+}$ intracellular cascades, that are activated by $\mathrm{ACTH}$ binding to $\mathrm{MC} 2 \mathrm{R}$, thus dampening the in vivo effects on mineralocorticoid secretion.

\section{Effects Against Reactive Oxygen Species}

ACTH-induced steroidogenesis reactions involve lipid peroxidation and production of reactive aldehyde metabolites that generate reactive oxygen species (ROS) and thus a considerable cellular oxidative stress. Consequently, several enzymes involved in the detoxification are mobilized in adrenal cells. Aldo-keto reductases participate into this detoxification process, and their expression is ACTHdependent (35). Moreover, in human and rat adrenal cells, seladin-1 (selective Alzheimer disease indicator 1, also named 24-dehydrocholesterol reductase) expression and redistribution to the nucleus occur after ACTH treatment (36). Finally, increased expression of SOD2, (mitochondrial superoxidase dismutase 2, a metalloenzyme involved in the scavenging of mitochondrial ROS) is also induced by ACTH (37). Therefore, ACTH regulates the expression of enzymes responsible for steroid biosynthesis and nonsteroidogenic enzymes involved in preventing ROS-induced cell toxicity. 


\section{Effects on Adrenal Growth and Adrenal Blood Flow}

An in vitro study showed that ACTH leads to increased cell death through the apoptosis of isolated cells in cultures of the adrenal cortex; however, the zona fasciculata and zona reticularis are more resistant to the cytotoxic and antimitogenic effects of ACTH than zona glomerulosa (38). In contrast with these results, in animal models, ACTH regulates adrenal gland trophicity $(28,39)$ and increases adrenal blood flow $(40)$. Furthermore, glucocorticoid-induced suppression of ACTH inhibits cell proliferation, induces apoptosis, decreases adrenal weight and cellularity of the adrenal cortex, and triggers vascular changes through loss of vascular endothelial growth factor protein expression, thereby causing regression of the vascular network (39). Moreover, knockout of the MC2R gene in mice leads to marked atrophy of the zona fasciculata (41) and high levels of MC2R expression in the undifferentiated zone, which contains stem cells supports the notion that ACTH may play an important role in adrenal cell differentiation and the importance of the ACTH-MC2R complex in adrenal development (42). Differences between in vitro cell cultures and in vivo models with regard to cell death by apoptosis are attributable to intraglandular factors, such as autonomic innervation and vascularization, supporting the importance of structural integrity and compartmentalization of the adrenal gland and suggesting that ACTH is primarily a differentiation factor that controls steroid secretion rather than a proliferative factor (38, $43,44)$.

\section{Effects on Gene Expression}

Different expression of key steroidogenic enzymes lead to zonespecific production of steroid hormones responsible for a distinct steroidogenic phenotype among the three constituent zones of the adrenal cortex (45-47). The Y1 mouse adrenal-cortical cell line, a model of normal mouse adrenal cortex cells, has been used to determine the effects of ACTH on gene expression. After ACTH stimulation, the levels of various transcripts were measured after $24 \mathrm{~h}$ (48). ACTH increased gene expression involved in cholesterol synthesis and mobilization and steroidogenic enzyme synthesis, confirming the importance of this hormone in the steroidogenic biosynthesis pathway. Conversely, $>50 \%$ of studied transcripts were downregulated and affected DNA replication, mitotic cell cycle, and RNA processing and nuclear transport, suggesting a possible modulatory effect of ACTH on adrenal cortex cell growth (48).

\section{Effects on Adrenal Medulla}

Although ACTH is known to be most effective on the adrenal cortex, some studies suggest that it can also influence the adrenal medulla. Hypophysectomy induces a decrease in both the adrenal epinephrine content and phenylethanolamine $\mathrm{N}$ methyltransferase (PNMT) - which converts norepinephrine to epinephrine-in rats. These alterations were restored upon ACTH injection $(49,50)$. The increase in PNMT by long-term ACTH treatment also occurs in healthy rats, suggesting that ACTH-induced adrenal stimulation influences the enzyme activities of adrenal medulla (51). Moreover, after ACTH stimulation test, both epinephrine and norepinephrine increased in adrenal venous blood in humans through ACTHinduced increase in blood flow and enzyme activities (52). These mechanisms are possibly mediated by ACTH-induced increase in adrenal medulla exposure to glucocorticoids, that are active inductors of PNMT (53).

\section{EXTRA-ADRENAL EFFECTS OF ACTH}

\section{Osteoarticular System}

Conventionally, ACTH activity through the increase in glucocorticoid level has a detrimental impact on bone mass, resulting in bone loss and osteoporosis. This is only true in endogenous or exogenous glucocorticoid excess $(54,55)$; at physiological levels, cortisol does not appear to have a negative effect on bone differentiation or proliferation (56). The prevalence of osteoporosis seems higher in patients with adrenal Cushing's syndrome, presenting typically with ACTH suppression, than in those with Cushing's disease (55, 57-59). These effects are undoubtedly due to adrenal androgen reduction derived from low ACTH levels, but a protective role of ACTH on bone has also been proposed. Osteoblasts express high-affinity ACTH receptors. Furthermore, high-dose ACTH stimulates osteoblastic proliferation and significantly increases osteoblast collagen synthesis (60-62). Conversely, lower ACTH doses seem to oppose osteoblast differentiation (60). ACTH stimulates VEGF production from osteoblasts and inhibits osteoclast differentiation in vitro $(63,64)$. Notably, murine osteoclasts are able to synthesize and release ACTH (61), so locally produced ACTH might also regulate bone metabolism. Finally, ACTH administration was proposed as a therapy for osteoarticular inflammatory conditions (65), for example it is included in guidelines for gout management (66), not only because of ACTH-induced glucocorticoid production but also because a direct role of ACTH was speculated $(67,68)$.

\section{Reproductive System}

Males. MC2R receptor is expressed in mouse fetal testis, in both gonocytes (69) and Leydig cells $(70,71)$. The testis MC2Rs seem to be functionally active and stimulate testosterone production in fetal and neonatal mice in a dose-dependent manner; however, the effect is lost in postpubertal mice (70), suggesting that ACTH regulates testosterone production in fetal but not in adult testes. The importance of ACTH signaling in the development of testicular adrenal rest tumors (TART) in conditions characterized by early exposure to increased levels of adrenocorticotropin will be discussed in the section on adrenal disorders. Data on the prostate are scarce. Prostate activated MC2R seems to promote cell proliferation in a concentrationdependent manner (72). Therefore, targeting MC2R signaling has been proposed as a novel strategy for prostate carcinoma treatment (73). Interestingly, local administration of ACTH1-24 into the hypothalamic periventricular region of male rats induced penile erection via melanocortin-3 receptor (74). 
Females. During a clinical trial on female premenopausal patients with Addison's disease, menstrual disturbances were recorded in four of nine patients after administration of highdose tetracosactide (ACTH1-24) (75). Robust MC2R expression was found in the glandular epithelium and lesser degree in stromal cells of human endometrium, suggesting the direct role of ACTH in regulating endometrial glandular secretion (76). Moreover, high ACTH1-24 concentrations promote involution of vascular structures in cultured decidua (76). MC2R is also expressed in bovine and rabbit ovaries, and a direct effect of ACTH on ovarian steroidogenesis was proposed $(77,78)$. However, despite in vitro studies have shown promising results in animal models, human studies are lacking. Most clinical trials on the role of ACTH in female reproduction have focused on its effects on androgen production in polycystic ovary syndrome (PCOS), and results suggested a possible contribution of dysregulated adrenal steroidogenesis in the pathogenesis of hyperandrogenism in PCOS (79).

\section{Adipocytes and Insulin Sensitivity}

The melanocortin system plays a crucial role in energy expenditure (80), but the direct role of ACTH is still unclear. MCR2 mRNA is expressed in murine adipocytes $(81,82)$. ACTH can stimulate lipolysis in vitro in rodent adipose tissue through MC2R-dependent cAMP/PKA activation $(80,83)$. MRAP seems to play a critical role in the regulation of $\mathrm{ACTH}$-induced lipolysis (84), and insulin resistance and glucose intolerance have been shown in MRAP2 knockout mice (85). However, ACTH does not seem to have a role in human adipose lipolysis $(86,87)$.

ACTH also seems to improve brown adipose tissue function in obese rat and mouse, an effect opposed by corticosterone. Moreover, ACTH increases glucose uptake in isolated brown adipocytes in the absence of insulin (88-90). Conversely, in cultured white mouse adipocytes, ACTH has been shown to directly induce insulin resistance and increase pro-inflammatory adipokine expression (82). Moreover, it has been found that ACTH is also a potent inhibitor of leptin expression (91). Waist circumference, prevalence of diabetes mellitus, and dyslipidemia are not significantly different in patients with pituitary or adrenal Cushing's syndrome $(55,92)$. To our knowledge, no clinical study has evaluated direct metabolic effects of ACTH in humans, either in physiological or pathological conditions.

\section{Immune System and Inflammation}

When analyzing the effects of ACTH on immunity, it is imperative to identify the distinction between glucocorticoidmediated and glucocorticoid-independent effects. In fact, glucocorticoids are powerful modulators of the immune system (93), but some effects of ACTH and other POMC-related peptides are independent from the adrenal response to corticotropin. MCRs have been described in most immune lineages (94), including $\mathrm{T}$ and $\mathrm{B}$ lymphocytes, CD $14^{+}$ monocytes, natural killer cells, and granulocytes. The activation of MCRs, and particularly of the MC3R, has antiinflammatory effects, including modulation of $\mathrm{T}$ lymphocyte cytotoxicity and tolerance $(95,96)$ and inhibition of NF- $\mathrm{\kappa B}$ signaling, which appears to mediate a reduction in inflammatory cytokine secretion and adhesion molecule expression (97-99). However, data on the direct impact of $\mathrm{ACTH}$ on inflammation are lacking, mostly due to the promiscuity of other MCRs. In fact, although MC2R is selective for ACTH, the possibility of cross-binding of other MCRs, such as MC3R (100), on immune cells has decreased the reliability of studies on $\mathrm{MC} \mathrm{R}^{-/-}$mice. Very recently, MC2R expression was confirmed on $\mathrm{T}$ regulatory Lymphocytes, and ACTH therapy was shown to promote allograft acceptance after heart transplant in mice (101). This supports a tolerogenic role of ACTH in inflammation, that would partially explain the efficacy in inflammatory diseases such as gout.

\section{Brain}

MC4R activation displays neuroprotective and neuroregenerative effects in several models of animal neurodegenerative diseases (102). ACTH has been found to promote oligodendrocyte protection (103) and neuron protection from inflammatory, excitotoxic, and apoptotic damages $(104,105)$. Dated research showed that rat embryo neurons respond to ACTH displaying a denser neuritic network (106) and displayed neuroprotective effects after hemorrhage insult by activating anti-inflammatory pathways (107, 108). Melanocortins have been proposed as therapy for brain injuries and several chronic neurodegenerative disorders (102). In epilepsy, ACTH is effective against infantile spasms, and it is administered to children suffering from intractable seizures and West syndrome $(109,110)$. Although the specific mechanisms for this antiepileptic effect remain unknown, beyond the "conventional" glucocorticoid production, ACTH seems to have a direct modulation of amygdala neurons leading to decreased production of the proconvulsant peptide CRH (110). Also, few data show that patients relapsing forms of multiple sclerosis may benefit from ACTH gel (111).

\section{Skin}

MC1R, expressed in melanocytes, plays a crucial role in the regulation of cutaneous pigmentation binding $\alpha$-melanocytestimulating hormone $(\alpha-\mathrm{MSH})$ and ACTH with the same affinity, with a dose dependent stimulation of melanogenesis and melanocytes proliferation (112-114). MCR1 extensive polymorphism is considered the major contributor to the diversity of human pigmentation (115). Interestingly, ultraviolet (UV) radiation exposure activates transcription of both keratinocytes and melanocytes POMC gene, resulting in increased local production of $\alpha-\mathrm{MSH}$ and ACTH, suggesting that they act as paracrine and autocrine regulators to protect the skin from UV damage $(116,117)$.

\section{ADRENAL DISORDERS}

Disorders of glucocorticoid secretion involve downstream or upstream dysregulation of ACTH secretion or activity. Even though several differences have been described between ACTH- 
dependent and independent hypercortisolism, chronic adrenal insufficiency (AI) is characterized by prolonged exposure to ACTH excess or defect without increased endogenous glucocorticoids or androgens (118), providing a valuable model for speculating on the effects of ACTH. Therefore, it will be the focus of this section.

Primary adrenal insufficiency (PAI) is characterized by adrenal failure, leading to insufficient cortisol secretion and increased ACTH levels (118). The increased ACTH and related peptide levels lead to skin hyperpigmentation, one of the pathognomonic characteristics of PAI, due to hyperstimulation of melanocytes. Aside from the effects on the skin, little is known on the systemic effects of increased ACTH in these patients. Conversely, patients with secondary adrenal insufficiency (SAI) have low or inappropriately normal ACTH levels, often due to pathologic processes or interventions involving pituitary or sellar or parasellar regions and leading to multiple hormone deficiencies (118). Another common cause of adrenal insufficiency (AI) is prolonged exposure to exogenous glucocorticoids, which is characterized by isolated low ACTH levels due to the suppression of physiological hypothalamicpituitary-adrenal (HPA) function.

\section{Genetic Forms of Adrenal Insufficiency}

Most genetic causes of HPA axis impairment are rare, and data are obtained by case reports or case series. Defects in ACTH synthesis, receptor, or signaling are among the mechanisms underlying genetic forms of AI. As previously mentioned, resistance to ACTH binding at the adrenal glands can be caused by mutations of the MC2R or MRAP gene and lead to type 1 and type 2 familial glucocorticoid deficiency, respectively. Alterations in ACTH synthesis include syndromes associated with pituitary hypoplasia or aplasia and isolated ACTH deficiency due to the disruption of POMC, PC1, or TPIT, the transcription factor responsible of POMC synthesis in the corticotroph pituitary cells (118).

Generally, the presenting signs and symptoms are hypoglycemia and jaundice due to AI, usually developing during the neonatal period or infancy although the age of onset is variable (119). Failure to thrive, seizures, and frequent infections are also common features. Patients with defective ACTH receptor or signaling present with hyperpigmentation and an unusually tall stature (120) due to the accumulation of ACTH and other POMC metabolites. Other similar genetic causes of AI characterized by increased ACTH and other POMC metabolites include defective steroidogenesis, peroxisome defects, mitochondrial defects, adrenal dysgenesis, and impaired redox homeostasis (118).

In contrast, in diseases affecting POMC synthesis ACTH levels are low or undetectable, and although these syndromes share AI with those formerly described, they differ under many other aspects. Interestingly, TPIT disruption only affects POMC production from the pituitary gland, whereas other sites of synthesis, such as the skin and hypothalamus, seem preserved (121); affected patients lack other signs and symptoms that are present in POMC defects. In fact, patients with monogenic POMC and PC1 defects show altered pigmentation and auburn hair, due to the lack of $\alpha$-melanocyte-stimulating hormone, and hyperphagic obesity usually presenting during infancy, due to defective POMC hypothalamic signaling (119).

\section{Acquired Adrenal Insufficiency}

The acquired forms of PAI and SAI are more common and better studied than their genetic counterparts. However, data on the contribution of ACTH in establishing the clinical picture and prognosis, aside from adrenal effects and canonical hyper- or hypo-pigmentation, are still limited. In male patients affected by congenital adrenal hyperplasia, prolonged and early exposure to high ACTH levels can lead to the development of testicular adrenal rest tumors (122), probably due to the proliferation of totipotent steroidogenic cells, which can ultimately cause infertility and altered testicular hormone secretion (122). It has been suggested that early exposure to high ACTH levels is crucial for the proliferation of pluripotent cells into TART (122). In some cases, a similar clinical picture has been described in other forms of PAI such as adrenoleukodystrophy (123).

\section{DISCUSSION}

The pleiotropic effects of ACTH are well known. However, its use as a therapeutic agent in the clinical practice is currently limited to selected diseases such as infantile spasms or antiinflammatory resistant gout, as previously described. In these conditions, especially in infantile spasms in which ACTH treatment is more broadly used, therapeutic effects and treatment-related adverse events largely rely on increased glucocorticoid secretion secondary to ACTH stimulation of the adrenal cortex (124). Furthermore, no conclusive evidence is available on the effects of its excess and defect in AI.

Even under optimal glucocorticoid replacement, patients affected by PAI show decreased quality of life (125) and increased mortality, with infections and cardiovascular and respiratory diseases as leading causes of death (126-128). In patients with hypopituitarism, AI has been associated with increased risk of death (129), and among patients with AI, those with SAI showed higher mortality (130); however, this result has not been confirmed by a more recent study (127). Cardiovascular mortality in patients with AI has been reported to be higher in female patients (128) and is associated with former comorbidities (131). Moreover, despite the presence of normal visceral fat, patients with PAI have an increased number of cardiovascular risk biomarkers (132). As previously described, in vitro studies have yielded confounding results on the effects of ACTH on insulin sensitivity and adipose tissue. Given the lack of conclusive data, studies on the possible role for ACTH excess in metabolic complications of PAI could provide useful insights.

Recent studies have shown immune alterations in patients with PAI and SAI $(23,133)$, which were partially restored by replacement therapies more respectful of circadian cortisol profile $(22,23)$. Even though subgroup analyses did not show any differences in outcomes after switch to modified release hydrocortisone between PAI and SAI (23), the study from Isidori 
and colleagues was not powered to investigate specific effects of ACTH on immune function in AI at baseline or after therapy switch, therefore possible differences could have been unrecognized. More studies are necessary to investigate this aspect.

\section{CONCLUSIONS}

The role of ACTH in maintaining adrenal homeostasis and participating in the HPA axis is self-evident. However, after an initial number of studies on its potential as a therapeutic strategy in many diseases and conditions, researchers seem to have abandoned the "corticotropin path" and have focused more on its downstream hormone pathways (glucocorticoids and androgens). Owing to the advances in knowledge and methodologies, it is time to rediscuss the role of ACTH in affecting general outcomes in adrenal diseases and the possible use of its noncanonical effects to address unmet needs.

\section{REFERENCES}

1. Li CH, Geschwind II, J.S. Dixon, Levy AL, Harris JI. Corticotropins (ACTH). I. Isolation of Alpha-Corticotropin From Sheep Pituitary Glands. J Biol Chem (1955) 213:171-85. doi: 10.1016/S0021-9258(18)71054-5

2. Gjerstad JK, Lightman SL, Spiga F. Role of Glucocorticoid Negative Feedback in the Regulation of HPA Axis Pulsatility. Stress (2018) 21:40316. doi: $10.1080 / 10253890.2018 .1470238$

3. Pignatti E, Fluck CE. Adrenal Cortex Development and Related Disorders Leading to Adrenal Insufficiency. Mol Cell Endocrinol (2021) 527:111206. doi: 10.1016/j.mce.2021.111206

4. Slominski A, Zbytek B, Szczesniewski A, Semak I, Kaminski J, Sweatman T, et al. CRH Stimulation of Corticosteroids Production in Melanocytes Is Mediated by ACTH. Am J Physiol Endocrinol Metab (2005) 288:E701-6. doi: 10.1152/ajpendo.00519.2004

5. Cawley NX, Li Z, Loh YP. 60 YEARS of POMC: Biosynthesis, Trafficking, and Secretion of Pro-Opiomelanocortin-Derived Peptides. J Mol Endocrinol (2016) 56:T77-97. doi: 10.1530/JME-15-0323

6. Moore HH, Kelly RB. Re-Routing of a Secretory Protein by Fusion With Human Growth Hormone Sequences. Nature (1986) 321:443-6. doi: $10.1038 / 321443 \mathrm{a} 0$

7. Cool DR, Fenger M, Snell CR, Loh YP. Identification of the Sorting Signal Motif Within Pro-Opiomelanocortin for the Regulated Secretory Pathway. J Biol Chem (1995) 270:8723-9. doi: 10.1074/ jbc. 270.15 .8723

8. Zhou A, Bloomquist BT, Mains RE. The Prohormone Convertases PC1 and PC2 Mediate Distinct Endoproteolytic Cleavages in a Strict Temporal Order During Proopiomelanocortin Biosynthetic Processing. J Biol Chem (1993) 268:1763-9. doi: 10.1016/S0021-9258(18)53918-1

9. Mountjoy KG, Robbins LS, Mortrud MT, Cone RD. The Cloning of a Family of Genes That Encode the Melanocortin Receptors. Science (1992) 257:1248-51. doi: 10.1126/science. 1325670

10. Metherell LA, Chapple JP, Cooray S, David A, Becker C, Ruschendorf F, et al. Mutations in MRAP, Encoding a New Interacting Partner of the ACTH Receptor, Cause Familial Glucocorticoid Deficiency Type 2. Nat Genet (2005) 37:166-70. doi: 10.1038/ng1501

11. Clark BJ, Ranganathan V, Combs R. Steroidogenic Acute Regulatory Protein Expression Is Dependent Upon Post-Translational Effects of CampDependent Protein Kinase a. Mol Cell Endocrinol (2001) 173:183-92. doi: 10.1016/S0303-7207(00)00410-X

12. Winnay JN, Hammer GD. Adrenocorticotropic Hormone-Mediated Signaling Cascades Coordinate a Cyclic Pattern of Steroidogenic Factor 1-

\section{AUTHOR CONTRIBUTIONS}

VH: substantial contributions to conception of the manuscript, analysis and interpretation of data, drafting the article, revising it critically, and final approval of the version to be submitted. IB, MM, ES, and VS: substantial contributions to conception of the manuscript, analysis and interpretation of data and drafting the article. ES: substantial contributions to revising the manuscript critically for important intellectual content, and final approval of the version to be submitted. AI: substantial contributions to conception and design of the manuscript, drafting the article and revising it critically for important intellectual content, and final approval of the version to be submitted. All authors contributed to the article and approved the submitted version.

\section{FUNDING}

The project was partially funded by the CHRONOIMAGE project (PRIN 2017HRTZYA) by MIUR.

Dependent Transcriptional Activation. Mol Endocrinol (2006) 20:147-66 doi: 10.1210/me.2005-0215

13. Lefrancois-Martinez AM, Blondet-Trichard A, Binart N, Val P, Chambon C, Sahut-Barnola I, et al. Transcriptional Control of Adrenal Steroidogenesis: Novel Connection Between Janus Kinase (JAK) 2 Protein and Protein Kinase a (PKA) Through Stabilization of Camp Response Element-Binding Protein (CREB) Transcription Factor. J Biol Chem (2011) 286:32976-85. doi: 10.1074/jbc.M111.218016

14. Gallo-Payet N, Battista MC. Steroidogenesis-Adrenal Cell Signal Transduction. Compr Physiol (2014) 4:889-964. doi: 10.1002/cphy.c130050

15. Minnetti M, Hasenmajer V, Pofi R, Venneri MA, Alexandraki KI, Isidori AM. Fixing the Broken Clock in Adrenal Disorders: Focus on Glucocorticoids and Chronotherapy. J Endocrinol (2020) 246:R13-31. doi: 10.1530/JOE-20-0066

16. Moreira AC, Antonini SR, de Castro M. MECHANISMS in ENDOCRINOLOGY: A Sense of Time of the Glucocorticoid Circadian Clock: From the Ontogeny to the Diagnosis of Cushing's Syndrome. Eur J Endocrinol (2018) 179:R1-R18. doi: 10.1530/EJE-18-0102

17. Dickmeis T, Weger BD, Weger M. The Circadian Clock and Glucocorticoids-Interactions Across Many Time Scales. Mol Cell Endocrinol (2013) 380:2-15. doi: 10.1016/j.mce.2013.05.012

18. Leliavski A, Dumbell R, Ott V, Oster H. Adrenal Clocks and the Role of Adrenal Hormones in the Regulation of Circadian Physiology. J Biol Rhythms (2015) 30:20-34. doi: 10.1177/0748730414553971

19. Oster H, Challet E, Ott V, Arvat E, de Kloet ER, Dijk DJ, et al. The Functional and Clinical Significance of the 24-Hour Rhythm of Circulating Glucocorticoids. Endocr Rev (2017) 38:3-45. doi: 10.1210/er.2015-1080

20. Campino C, Valenzuela FJ, Torres-Farfan C, Reynolds HE, Abarzua-Catalan L, Arteaga E, et al. Melatonin Exerts Direct Inhibitory Actions on ACTH Responses in the Human Adrenal Gland. Horm Metab Res (2011) 43:33742. doi: 10.1055/s-0031-1271693

21. Angelousi A, Nasiri-Ansari N, Karapanagioti A, Kyriakopoulos G, Aggeli C, Zografos G, et al. Expression of Clock-Related Genes in Benign and Malignant Adrenal Tumors. Endocrine (2020) 68:650-9. doi: 10.1007/s12020-020-02246-Z

22. Venneri MA, Hasenmajer V, Fiore D, Sbardella E, Pofi R, Graziadio C, et al. Circadian Rhythm of Glucocorticoid Administration Entrains Clock Genes in Immune Cells: A DREAM Trial Ancillary Study. J Clin Endocrinol Metab (2018) 103:2998-3009. doi: 10.1210/jc.2018-00346

23. Isidori AM, Venneri MA, Graziadio C, Simeoli C, Fiore D, Hasenmajer V, et al. Effect of Once-Daily, Modified-Release Hydrocortisone Versus Standard Glucocorticoid Therapy on Metabolism and Innate Immunity in Patients With Adrenal Insufficiency (DREAM): A Single-Blind, Randomised Controlled Trial. Lancet Diabetes Endocrinol (2018) 6:173-85. doi: 10.1016/S2213-8587(17)30398-4 
24. Jefcoate CR, McNamara BC, Artemenko I, Yamazaki T. Regulation of Cholesterol Movement to Mitochondrial Cytochrome P450scc in Steroid Hormone Synthesis. J Steroid Biochem Mol Biol (1992) 43:751-67. doi: 10.1016/0960-0760(92)90305-3

25. Lehoux JG, Fleury A, Ducharme L. The Acute and Chronic Effects of Adrenocorticotropin on the Levels of Messenger Ribonucleic Acid and Protein of Steroidogenic Enzymes in Rat Adrenal In Vivo. Endocrinology (1998) 139:3913-22. doi: 10.1210/endo.139.9.6196

26. Clark BJ, Wells J, King SR, Stocco DM. The Purification, Cloning, and Expression of a Novel Luteinizing Hormone-Induced Mitochondrial Protein in MA-10 Mouse Leydig Tumor Cells. Characterization of the Steroidogenic Acute Regulatory Protein (Star). J Biol Chem (1994) 269:28314-22. doi: 10.1016/S0021-9258(18)46930-X

27. Vinson GP. Adrenocortical Zonation and ACTH. Microsc Res Tech (2003) 61:227-39. doi: 10.1002/jemt.10331

28. Mazzocchi G, Malendowicz LK, Rebuffat P, Robba C, Gottardo G, Nussdorfer GG. Short- and Long-Term Effects of ACTH on the Adrenal Zona Glomerulosa of the Rat. A Coupled Stereological and Enzymological Study. Cell Tissue Res (1986) 243:303-10. doi: 10.1007/BF00251044

29. Daidoh H, Morita H, Mune T, Murayama M, Hanafusa J, Ni H, et al. Responses of Plasma Adrenocortical Steroids to Low Dose ACTH in Normal Subjects. Clin Endocrinol (Oxf) (1995) 43:311-5. doi: 10.1111/j.1365-2265.1995.tb02037.x

30. Markou A, Sertedaki A, Kaltsas G, Androulakis II, Marakaki C, Pappa T, et al. Stress-Induced Aldosterone Hyper-Secretion in a Substantial Subset of Patients With Essential Hypertension. J Clin Endocrinol Metab (2015) 100:2857-64. doi: 10.1210/jc.2015-1268

31. Crivello JF, Gill GN. Induction of Cultured Bovine Adrenocortical Zona Glomerulosa Cell 17-Hydroxylase Activity by ACTH. Mol Cell Endocrinol (1983) 30:97-107. doi: 10.1016/0303-7207(83)90204-6

32. Bird IM, Pasquarette MM, Rainey WE, Mason JI. Differential Control of 17 Alpha-Hydroxylase and 3 Beta-Hydroxysteroid Dehydrogenase Expression in Human Adrenocortical H295R Cells. J Clin Endocrinol Metab (1996) 81:2171-8. doi: 10.1210/jcem.81.6.8964847

33. Nishimoto K, Rainey WE, Bollag WB, Seki T. Lessons From the Gene Expression Pattern of the Rat Zona Glomerulosa. Mol Cell Endocrinol (2013) 371:107-13. doi: 10.1016/j.mce.2012.12.023

34. Seely EW, Conlin PR, Brent GA, Dluhy RG. Adrenocorticotropin Stimulation of Aldosterone: Prolonged Continuous Versus Pulsatile Infusion. J Clin Endocrinol Metab (1989) 69:1028-32. doi: 10.1210/jcem-69-5-1028

35. Martinez A, Aigueperse C, Val P, Dussault M, Tournaire C, Berger M, et al. Physiological Functions and Hormonal Regulation of Mouse Vas Deferens Protein (AKR1B7) in Steroidogenic Tissues. Chem Biol Interact (2001) 130132:903-17. doi: 10.1016/S0009-2797(00)00244-1

36. Battista MC, Roberge C, Martinez A, Gallo-Payet N. 24-Dehydrocholesterol Reductase/Seladin-1: A Key Protein Differentially Involved in Adrenocorticotropin Effects Observed in Human and Rat Adrenal Cortex. Endocrinology (2009) 150:4180-90. doi: 10.1210/en.2009-0410

37. Chinn AM, Ciais D, Bailly S, Chambaz E, LaMarre J, Feige JJ. Identification of Two Novel ACTH-Responsive Genes Encoding Manganese-Dependent Superoxide Dismutase (SOD2) and the Zinc Finger Protein TIS11b [Tetradecanoyl Phorbol Acetate (TPA)-Inducible Sequence 11b]. Mol Endocrinol (2002) 16:1417-27. doi: 10.1210/mend.16.6.0844

38. Mattos GE, Jacysyn JF, Amarante-Mendes GP, Lotfi CF. Comparative Effect of FGF2, Synthetic Peptides 1-28 N-POMC and ACTH on Proliferation in Rat Adrenal Cell Primary Cultures. Cell Tissue Res (2011) 345:343-56. doi: 10.1007/s00441-011-1220-8

39. Thomas M, Keramidas M, Monchaux E, Feige JJ. Dual Hormonal Regulation of Endocrine Tissue Mass and Vasculature by Adrenocorticotropin in the Adrenal Cortex. Endocrinology (2004) 145:4320-9. doi: 10.1210/en.2004-0179

40. Shah AJ, Kriska T, Gauthier KM, Falck JR, Campbell WB. Effect of Angiotensin II and ACTH on Adrenal Blood Flow in the Male Rat Adrenal Gland in Vivo. Endocrinology (2018) 159:217-26. doi: 10.1210/en.2016-1594

41. Chida D, Nakagawa S, Nagai S, Sagara H, Katsumata H, Imaki T, et al. Melanocortin 2 Receptor Is Required for Adrenal Gland Development, Steroidogenesis, and Neonatal Gluconeogenesis. Proc Natl Acad Sci USA (2007) 104:18205-10. doi: 10.1073/pnas.0706953104

42. Gorrigan RJ, Guasti L, King P, Clark AJ, Chan LF. Localisation of the Melanocortin-2-Receptor and Its Accessory Proteins in the Developing and
Adult Adrenal Gland. J Mol Endocrinol (2011) 46:227-32. doi: 10.1530/JME11-0011

43. Shepherd SP, Holzwarth MA. Chromaffin-Adrenocortical Cell Interactions: Effects of Chromaffin Cell Activation in Adrenal Cell Cocultures. Am J Physiol Cell Physiol (2001) 280:C61-71. doi: 10.1152/ajpcell.2001.280.1.C61

44. Carsia RV, Tilly KI, Tilly JL. Hormonal Modulation of Apoptosis in the Rat Adrenal Gland In Vitro Is Dependent on Structural Integrity. Endocrine (1997) 7:377-81. doi: 10.1007/BF02801333

45. Xing Y, Edwards MA, Ahlem C, Kennedy M, Cohen A, Gomez-Sanchez CE, et al. The Effects of ACTH on Steroid Metabolomic Profiles in Human Adrenal Cells. J Endocrinol (2011) 209:327-35. doi: 10.1530/JOE-10-0493

46. Nishimoto K, Rigsby CS, Wang T, Mukai K, Gomez-Sanchez CE, Rainey WE, et al. Transcriptome Analysis Reveals Differentially Expressed Transcripts in Rat Adrenal Zona Glomerulosa and Zona Fasciculata. Endocrinology (2012) 153:1755-63. doi: 10.1210/en.2011-1915

47. Rege J, Nakamura Y, Wang T, Merchen TD, Sasano H, Rainey WE. Transcriptome Profiling Reveals Differentially Expressed Transcripts Between the Human Adrenal Zona Fasciculata and Zona Reticularis. J Clin Endocrinol Metab (2014) 99:E518-27. doi: 10.1210/jc.2013-3198

48. Schimmer BP, Cordova M, Cheng H, Tsao A, Goryachev AB, Schimmer AD, et al. Global Profiles of Gene Expression Induced by Adrenocorticotropin in Y1 Mouse Adrenal Cells. Endocrinology (2006) 147:2357-67. doi: 10.1210/en.2005-1526

49. Wurtman RJ. Control of Epinephrine Synthesis in the Adrenal Medulla by the Adrenal Cortex: Hormonal Specificity and Dose-Response Characteristics. Endocrinology (1966) 79:608-14. doi: 10.1210/endo-79-3-608

50. Wurtman RJ, Axelrod J. Adrenaline Synthesis: Control by the Pituitary Gland and Adrenal Glucocorticoids. Science (1965) 150:1464-5. doi: 10.1126/science.150.3702.1464

51. Simonyi A, Fekete MI, Kenessey A, Paldi-Haris P, Graf L. Prolonged ACTH Treatment Increases Trypsin-Like and Phenylethanolamine-NMethyltransferase (PNMT) Activity in the Adrenals. Eur J Pharmacol (1984) 106:465-6. doi: 10.1016/0014-2999(84)90745-3

52. Valenta LJ, Elias AN, Eisenberg H. ACTH Stimulation of Adrenal Epinephrine and Norepinephrine Release. Horm Res (1986) 23:16-20. doi: $10.1159 / 000180283$

53. Wurtman RJ. Stress and the Adrenocortical Control of Epinephrine Synthesis. Metabolism (2002) 51:11-4. doi: 10.1053/meta.2002.33185

54. Hardy RS, Zhou H, Seibel MJ, Cooper MS. Glucocorticoids and Bone: Consequences of Endogenous and Exogenous Excess and Replacement Therapy. Endocr Rev (2018) 39:519-48. doi: 10.1210/er.2018-00097

55. Pivonello R, Isidori AM, De Martino MC, Newell-Price J, Biller BM, Colao A. Complications of Cushing's Syndrome: State of the Art. Lancet Diabetes Endocrinol (2016) 4:611-29. doi: 10.1016/S2213-8587(16)00086-3

56. Boden SD, Hair G, Titus L, Racine M, McCuaig K, Wozney JM, et al. Glucocorticoid-Induced Differentiation of Fetal Rat Calvarial Osteoblasts Is Mediated by Bone Morphogenetic Protein-6. Endocrinology (1997) 138:2820-8. doi: 10.1210/endo.138.7.5125

57. Minetto M, Reimondo G, Osella G, Ventura M, Angeli A, Terzolo M. Bone Loss Is More Severe in Primary Adrenal Than in Pituitary-Dependent Cushing's Syndrome. Osteoporos Int (2004) 15:855-61. doi: 10.1007/s00198-004-1616-3

58. Ohmori N, Nomura K, Ohmori K, Kato Y, Itoh T, Takano K. Osteoporosis Is More Prevalent in Adrenal Than in Pituitary Cushing's Syndrome. Endocr J (2003) 50:1-7. doi: 10.1507/endocrj.50.1

59. Guo W, Li F, Zhu C, Wang B, Wang K, Dai C, et al. Effect of Hypercortisolism on Bone Mineral Density and Bone Metabolism: A Potential Protective Effect of Adrenocorticotropic Hormone in Patients With Cushing's Disease. J Int Med Res (2018) 46:492-503. doi: 10.1177/0300060517725660

60. Isales CM, Zaidi M, Blair HC. ACTH is a Novel Regulator of Bone Mass. Ann N Y Acad Sci (2010) 1192:110-6. doi: 10.1111/j.1749-6632.2009.05231.x

61. Zhong Q, Sridhar S, Ruan L, Ding KH, Xie D, Insogna K, et al. Multiple Melanocortin Receptors are Expressed in Bone Cells. Bone (2005) 36:820-31. doi: 10.1016/j.bone.2005.01.020

62. Dumont LM, Wu CS, Tatnell MA, Cornish J, Mountjoy KG. Evidence for Direct Actions of Melanocortin Peptides on Bone Metabolism. Peptides (2005) 26:1929-35. doi: 10.1016/j.peptides.2004.12.034

63. Zaidi M, Sun L, Robinson LJ, Tourkova IL, Liu L, Wang Y, et al. ACTH Protects Against Glucocorticoid-Induced Osteonecrosis of Bone. Proc Natl Acad Sci USA (2010) 107:8782-7. doi: 10.1073/pnas.0912176107 
64. Tourkova IL, Liu L, Sutjarit N, Larrouture QC, Luo J, Robinson LJ, et al. Adrenocorticotropic Hormone and 1,25-Dihydroxyvitamin D3 Enhance Human Osteogenesis In Vitro by Synergistically Accelerating the Expression of Bone-Specific Genes. Lab Invest (2017) 97:1072-83. doi: 10.1038/labinvest.2017.62

65. Schlesinger N. Overview of the Management of Acute Gout and the Role of Adrenocorticotropic Hormone. Drugs (2008) 68:407-15. doi: 10.2165/ 00003495-200868040-00002

66. FitzGerald JD, Dalbeth N, Mikuls T, Brignardello-Petersen R, Guyatt G, Abeles AM, et al. American College of Rheumatology Guideline for the Management of Gout. Arthritis Care Res (Hoboken) (2020) 72:744-60. doi: 10.1002/acr.24180

67. Ritter J, Kerr LD, Valeriano-Marcet J, Spiera H. ACTH Revisited: Effective Treatment for Acute Crystal Induced Synovitis in Patients With Multiple Medical Problems. J Rheumatol (1994) 21:696-9.

68. Bohm M, Grassel S. Role of Proopiomelanocortin-Derived Peptides and Their Receptors in the Osteoarticular System: From Basic to Translational Research. Endocr Rev (2012) 33:623-51. doi: 10.1210/er.2011-1016

69. Nimura M, Udagawa J, Hatta T, Hashimoto R, Otani H. Spatial and Temporal Patterns of Expression of Melanocortin Type 2 and 5 Receptors in the Fetal Mouse Tissues and Organs. Anat Embryol (Berl) (2006) 211:10917. doi: 10.1007/s00429-005-0066-9

70. O’Shaughnessy PJ, Fleming LM, Jackson G, Hochgeschwender U, Reed P, Baker PJ. Adrenocorticotropic Hormone Directly Stimulates Testosterone Production by the Fetal and Neonatal Mouse Testis. Endocrinology (2003) 144:3279-84. doi: 10.1210/en.2003-0277

71. Johnston H, King PJ, O'Shaughnessy PJ. Effects of ACTH and Expression of the Melanocortin-2 Receptor in the Neonatal Mouse Testis. Reproduction (2007) 133:1181-7. doi: 10.1530/REP-06-0359

72. Hafiz S, Dennis JC, Schwartz D, Judd R, Tao YX, Khazal K, et al. Expression of Melanocortin Receptors in Human Prostate Cancer Cell Lines: MC2R Activation by ACTH Increases Prostate Cancer Cell Proliferation. Int J Oncol (2012) 41:1373-80. doi: 10.3892/ijo.2012.1574

73. Bouw E, Huisman M, Neggers SJ, Themmen AP, van der Lely AJ, Delhanty PJ. Development of Potent Selective Competitive-Antagonists of the Melanocortin Type 2 Receptor. Mol Cell Endocrinol (2014) 394:99-104. doi: 10.1016/j.mce.2014.07.003

74. Argiolas A, Melis MR, Murgia S, Schioth HB. ACTH- and Alpha-MSHInduced Grooming, Stretching, Yawning and Penile Erection in Male Rats: Site of Action in the Brain and Role of Melanocortin Receptors. Brain Res Bull (2000) 51:425-31. doi: 10.1016/S0361-9230(99)00270-1

75. Gan EH, MacArthur K, Mitchell AL, Hughes BA, Perros P, Ball SG, et al. Residual Adrenal Function in Autoimmune Addison's Disease: Improvement After Tetracosactide (ACTH1-24) Treatment. J Clin Endocrinol Metab (2014) 99:111-8. doi: 10.1210/jc.2013-2449

76. Lantang AM, Innes BA, Gan EH, Pearce SH, Lash GE. Expression of Melanocortin Receptors in Human Endometrium. Hum Reprod (2015) 30:2404-10. doi: 10.1093/humrep/dev188

77. Guelfi G, Zerani M, Brecchia G, Parillo F, Dall'Aglio C, Maranesi M, et al. Direct Actions of ACTH on Ovarian Function of Pseudopregnant Rabbits. Mol Cell Endocrinol (2011) 339:63-71. doi: 10.1016/j.mce.2011.03.017

78. Amweg AN, Paredes A, Salvetti NR, Lara HE, Ortega HH. Expression of Melanocortin Receptors mRNA, and Direct Effects of ACTH on Steroid Secretion in the Bovine Ovary. Theriogenology (2011) 75:628-37. doi: 10.1016/j.theriogenology.2010.10.003

79. Maas KH, Chuan S, Harrison E, Cook-Andersen H, Duleba AJ, Chang RJ. Androgen Responses to Adrenocorticotropic Hormone Infusion Among Individual Women With Polycystic Ovary Syndrome. Fertil Steril (2016) 106:1252-7. doi: 10.1016/j.fertnstert.2016.06.039

80. Boston BA. The Role of Melanocortins in Adipocyte Function. Ann N Y Acad Sci (1999) 885:75-84. doi: 10.1111/j.1749-6632.1999.tb08666.x

81. Boston BA, Cone RD. Characterization of Melanocortin Receptor Subtype Expression in Murine Adipose Tissues and in the 3T3-L1 Cell Line. Endocrinology (1996) 137:2043-50. doi: 10.1210/endo.137.5.8612546

82. Iwen KA, Senyaman O, Schwartz A, Drenckhan M, Meier B, Hadaschik D, et al. Melanocortin Crosstalk With Adipose Functions: ACTH Directly Induces Insulin Resistance, Promotes a Pro-Inflammatory Adipokine Profile and Stimulates UCP-1 in Adipocytes. J Endocrinol (2008) 196:46572. doi: 10.1677/JOE-07-0299
83. Cho KJ, Shim JH, Cho MC, Choe YK, Hong JT, Moon DC, et al. Signaling Pathways Implicated in Alpha-Melanocyte Stimulating Hormone-Induced Lipolysis in 3T3-L1 Adipocytes. J Cell Biochem (2005) 96:869-78. doi: $10.1002 /$ jcb. 20561

84. Zhang X, Saarinen AM, Campbell LE, De Filippis EA, Liu J. Regulation of Lipolytic Response and Energy Balance by Melanocortin 2 Receptor Accessory Protein (MRAP) in Adipocytes. Diabetes (2018) 67:222-34. doi: $10.2337 / \mathrm{db} 17-0862$

85. Rouault AAJ, Lee AA, Sebag JA. Regions of MRAP2 Required for the Inhibition of Orexin and Prokineticin Receptor Signaling. Biochim Biophys Acta Mol Cell Res (2017) 1864:2322-9. doi: 10.1016/j.bbamcr.2017.09.008

86. Kiwaki K, Levine JA. Differential Effects of Adrenocorticotropic Hormone on Human and Mouse Adipose Tissue. J Comp Physiol B (2003) 173:675-8. doi: 10.1007/s00360-003-0377-1

87. Moller CL, Pedersen SB, Richelsen B, Conde-Frieboes KW, Raun K, Grove $\mathrm{KL}$, et al. Melanocortin Agonists Stimulate Lipolysis in Human Adipose Tissue Explants But Not in Adipocytes. BMC Res Notes (2015) 8:559. doi: 10.1186/s13104-015-1539-4

88. Marette A, Bukowiecki LJ. Mechanism of Norepinephrine Stimulation of Glucose Transport in Isolated Rat Brown Adipocytes. Int J Obes (1990) 14:857-67.

89. York DA, Al-Baker I. Effect of Corticotropin on Brown Adipose Tissue Mitochondrial GDP Binding in Obese Rats. Biochem J (1984) 223:263-6. doi: 10.1042/bj2230263

90. van den Beukel JC, Grefhorst A, Quarta C, Steenbergen J, Mastroberardino PG, Lombes M, et al. Direct Activating Effects of Adrenocorticotropic Hormone $(\mathrm{ACTH})$ on Brown Adipose Tissue are Attenuated by Corticosterone. FASEB J (2014) 28:4857-67. doi: 10.1096/fj.14-254839

91. Norman D, Isidori AM, Frajese V, Caprio M, Chew SL, Grossman AB, et al. ACTH and Alpha-MSH Inhibit Leptin Expression and Secretion in 3T3-L1 Adipocytes: Model for a Central-Peripheral Melanocortin-Leptin Pathway. Mol Cell Endocrinol (2003) 200:99-109. doi: 10.1016/S0303-7207(02)00410-0

92. Giordano R, Picu A, Marinazzo E, D’Angelo V, Berardelli R, Karamouzis I, et al. Metabolic and Cardiovascular Outcomes in Patients With Cushing's Syndrome of Different Aetiologies During Active Disease and 1 Year After Remission. Clin Endocrinol (Oxf) (2011) 75:354-60. doi: 10.1111/j.13652265.2011.04055.x

93. Hasenmajer V, Sbardella E, Sciarra F, Minnetti M, Isidori AM, Venneri MA. The Immune System in Cushing's Syndrome. Trends Endocrinol Metab (2020) 31:655-69. doi: 10.1016/j.tem.2020.04.004

94. Andersen GN, Hagglund M, Nagaeva O, Frangsmyr L, Petrovska R, Mincheva-Nilsson L, et al. Quantitative Measurement of the Levels of Melanocortin Receptor Subtype 1, 2, 3 and 5 and Pro-Opio-Melanocortin Peptide Gene Expression in Subsets of Human Peripheral Blood Leucocytes. Scand J Immunol (2005) 61:279-84. doi: 10.1111/j.1365-3083.2005.01565.x

95. Loser K, Brzoska T, Oji V, Auriemma M, Voskort M, Kupas V, et al. The Neuropeptide Alpha-Melanocyte-Stimulating Hormone is Critically Involved in the Development of Cytotoxic CD8+ T Cells in Mice and Humans. PloS One (2010) 5:e8958. doi: 10.1371/journal.pone.0008958

96. Taylor A, Namba K. In Vitro Induction of CD25+ CD4+ Regulatory T Cells by the Neuropeptide Alpha-Melanocyte Stimulating Hormone (Alpha-MSH). Immunol Cell Biol (2001) 79:358-67. doi: 10.1046/j.1440-1711.2001.01022.x

97. Mandrika I, Muceniece R, Wikberg JE. Effects of Melanocortin Peptides on Lipopolysaccharide/Interferon-Gamma-Induced NF-KappaB DNA Binding and Nitric Oxide Production in Macrophage-Like RAW 264.7 Cells: Evidence for Dual Mechanisms of Action. Biochem Pharmacol (2001) 61:613-21. doi: 10.1016/S0006-2952(00)00583-9

98. Getting SJ, Allcock GH, Flower R, Perretti M. Natural and Synthetic Agonists of the Melanocortin Receptor Type 3 Possess Anti-Inflammatory Properties. J Leukoc Biol (2001) 69:98-104. doi: 10.1189/jlb.69.1.98

99. Getting SJ, Di Filippo C, Christian HC, Lam CW, Rossi F, D’Amico M, et al. MC-3 Receptor and the Inflammatory Mechanisms Activated in Acute Myocardial Infarct. J Leukoc Biol (2004) 76:845-53. doi: 10.1189/jlb.0306175

100. Getting SJ, Perretti M. MC3-R as a Novel Target for Antiinflammatory Therapy. Drug News Perspect (2000) 13:19-27.

101. Zhao J, Jiang L, Uehara M, Banouni N, Al Dulaijan BS, Azzi J, et al. ACTH Treatment Promotes Murine Cardiac Allograft Acceptance. JCI Insight (2021) 6:e143385. doi: 10.1172/jci.insight.143385 
102. Giuliani D, Ottani A, Neri L, Zaffe D, Grieco P, Jochem J, et al. Multiple Beneficial Effects of Melanocortin MC4 Receptor Agonists in Experimental Neurodegenerative Disorders: Therapeutic Perspectives. Prog Neurobiol (2017) 148:40-56. doi: 10.1016/j.pneurobio.2016.11.004

103. Lisak RP, Nedelkoska L, Benjamins JA. The Melanocortin ACTH 1-39 Promotes Protection of Oligodendrocytes by Astroglia. J Neurol Sci (2016) 362:21-6. doi: 10.1016/j.jns.2016.01.009

104. Lisak RP, Nedelkoska L, Bealmear B, Benjamins JA. Melanocortin Receptor Agonist ACTH 1-39 Protects Rat Forebrain Neurons From Apoptotic, Excitotoxic and Inflammation-Related Damage. Exp Neurol (2015) 273:161-7. doi: 10.1016/j.expneurol.2015.08.012

105. Benjamins JA, Nedelkoska L, Lisak RP. Adrenocorticotropin Hormone 1-39 Promotes Proliferation and Differentiation of Oligodendroglial Progenitor Cells and Protects From Excitotoxic and Inflammation-Related Damage. J Neurosci Res (2014) 92:1243-51. doi: 10.1002/jnr.23416

106. Hol EM, Gispen WH, Bar PR. ACTH-Related Peptides: Receptors and Signal Transduction Systems Involved in Their Neurotrophic and Neuroprotective Actions. Peptides (1995) 16:979-93. doi: 10.1016/0196-9781(95)00017-E

107. Guarini S, Cainazzo MM, Giuliani D, Mioni C, Altavilla D, Marini H, et al. Adrenocorticotropin Reverses Hemorrhagic Shock in Anesthetized Rats Through the Rapid Activation of a Vagal Anti-Inflammatory Pathway. Cardiovasc Res (2004) 63:357-65. doi: 10.1016/j.cardiores.2004.03.029

108. Martins CA, Neves LT, de Oliveira M, Bagatini PB, Barboza R, Mestriner RG, et al. Neuroprotective Effect of ACTH on Collagenase-Induced PeriIntraventricular Hemorrhage in Newborn Male Rats. Sci Rep (2020) 10:17734. doi: 10.1038/s41598-020-74712-7

109. Yin J, Lu Q, Yin F, Wang Y, He F, Wu L, et al. Effectiveness and Safety of Different Once-Daily Doses of Adrenocorticotropic Hormone for Infantile Spasms. Paediatr Drugs (2017) 19:357-65. doi: 10.1007/s40272-017-0225-5

110. Brunson KL, Avishai-Eliner S, Baram TZ. ACTH Treatment of Infantile Spasms: Mechanisms of its Effects in Modulation of Neuronal Excitability. Int Rev Neurobiol (2002) 49:185-97. doi: 10.1016/S0074-7742(02)49013-7

111. Berkovich R, Agius MA. Mechanisms of Action of ACTH in the Management of Relapsing Forms of Multiple Sclerosis. Ther Adv Neurol Disord (2014) 7:83-96. doi: 10.1177/1756285613518599

112. Abdel-Malek ZA, Knittel J, Kadekaro AL, Swope VB, Starner R. The Melanocortin 1 Receptor and the UV Response of Human Melanocytes-a Shift in Paradigm. Photochem Photobiol (2008) 84:501-8. doi: 10.1111/ j.1751-1097.2008.00294.x

113. Abdel-Malek Z, Swope VB, Suzuki I, Akcali C, Harriger MD, Boyce ST, et al. Mitogenic and Melanogenic Stimulation of Normal Human Melanocytes by Melanotropic Peptides. Proc Natl Acad Sci USA (1995) 92:1789-93. doi: 10.1073/pnas.92.5.1789

114. Wolf Horrell EM, Boulanger MC, D’Orazio JA. Melanocortin 1 Receptor: Structure, Function, and Regulation. Front Genet (2016) 7:95. doi: 10.3389/ fgene.2016.00095

115. Rana BK, Hewett-Emmett D, Jin L, Chang BH, Sambuughin N, Lin M, et al. High Polymorphism at the Human Melanocortin 1 Receptor Locus. Genetics (1999) 151:1547-57. doi: 10.1093/genetics/151.4.1547

116. Wakamatsu K, Graham A, Cook D, Thody AJ. Characterisation of ACTH Peptides in Human Skin and Their Activation of the Melanocortin-1 Receptor. Pigment Cell Res (1997) 10:288-97. doi: 10.1111/j.1600-0749.1997.tb00688.x

117. Slominski A, Tobin DJ, Shibahara S, Wortsman J. Melanin Pigmentation in Mammalian Skin and Its Hormonal Regulation. Physiol Rev (2004) 84:1155228. doi: 10.1152 /physrev.00044.2003

118. Husebye ES, Pearce SH, Krone NP, Kampe O. Adrenal Insufficiency. Lancet (2021) 397:613-29. doi: 10.1016/S0140-6736(21)00136-7

119. Buonocore F, McGlacken-Byrne SM, Del Valle I, Achermann JC. Current Insights Into Adrenal Insufficiency in the Newborn and Young Infant. Front Pediatr (2020) 8:619041. doi: 10.3389/fped.2020.619041

120. Chung TT, Chan LF, Metherell LA, Clark AJ. Phenotypic Characteristics of Familial Glucocorticoid Deficiency (FGD) Type 1 and 2. Clin Endocrinol (Oxf) (2010) 72:589-94. doi: 10.1111/j.1365-2265.2009.03663.x

121. Pulichino AM, Vallette-Kasic S, Couture C, Gauthier Y, Brue T, David M, et al. Human and Mouse TPIT Gene Mutations Cause Early Onset Pituitary ACTH Deficiency. Genes Dev (2003) 17:711-6. doi: 10.1101/gad.1065603

122. Engels M, Span PN, van Herwaarden AE, Sweep F, Stikkelbroeck N, Claahsen-van der Grinten HL. Testicular Adrenal Rest Tumors: Current
Insights on Prevalence, Characteristics, Origin, and Treatment. Endocr Rev (2019) 40:973-87. doi: 10.1210/er.2018-00258

123. Tresoldi AS, Betella N, Hasenmajer V, Pozza C, Vena W, Fiamengo B, et al. Bilateral Testicular Masses and Adrenal Insufficiency: Is Congenital Adrenal Hyperplasia the Only Possible Diagnosis? First Two Cases of TARTS Described in Addison-Only X-Linked Adrenoleukodystrophy and a Brief Review of Literature. J Endocrinol Invest (2021) 44:391-402. doi: 10.1007/ s40618-020-01362-x

124. Baba S, Okanishi T, Homma Y, Yoshida T, Goto T, Fukasawa T, et al. Efficacy of Long-Term Adrenocorticotropic Hormone Therapy for West Syndrome: A Retrospective Multicenter Case Series. Epilepsia Open (2021) 6:402-12. doi: 10.1002/epi4.12497

125. Lovas K, Loge JH, Husebye ES. Subjective Health Status in Norwegian Patients With Addison's Disease. Clin Endocrinol (Oxf) (2002) 56:581-8. doi: 10.1046/j.1365-2265.2002.01466.x

126. Bergthorsdottir R, Leonsson-Zachrisson M, Oden A, Johannsson G. Premature Mortality in Patients With Addison's Disease: A Population-Based Study. J Clin Endocrinol Metab (2006) 91:4849-53. doi: 10.1210/jc.2006-0076

127. Ngaosuwan K, Johnston DG, Godsland IF, Cox J, Majeed A, Quint JK, et al. Increased Mortality Risk in Patients With Primary and Secondary Adrenal Insufficiency. J Clin Endocrinol Metab (2021) 106(7):e2759-68. doi: 10.1530/ endoabs.73.PEP11.7

128. Skov J, Sundstrom A, Ludvigsson JF, Kampe O, Bensing S. Sex-Specific Risk of Cardiovascular Disease in Autoimmune Addison Disease-a PopulationBased Cohort Study. J Clin Endocrinol Metab (2019) 104:2031-40. doi: 10.1210/jc.2018-02298

129. Burman P, Mattsson AF, Johannsson G, Hoybye C, Holmer H, Dahlqvist P, et al. Deaths Among Adult Patients With Hypopituitarism: Hypocortisolism During Acute Stress, and De Novo Malignant Brain Tumors Contribute to an Increased Mortality. J Clin Endocrinol Metab (2013) 98:1466-75. doi: 10.1210/jc.2012-4059

130. Quinkler M, Ekman B, Zhang P, Isidori AM, Murray RD, Investigators E-A. Mortality Data From the European Adrenal Insufficiency Registry-Patient Characterization and Associations. Clin Endocrinol (Oxf) (2018) 89:30-5. doi: $10.1111 /$ cen.13609

131. Ngaosuwan K, Johnston DG, Godsland IF, Cox J, Majeed A, Quint JK, et al. Cardiovascular Disease in Patients With Primary and Secondary Adrenal Insufficiency and the Role of Comorbidities. J Clin Endocrinol Metab (2021) 106(5):1284-93. doi: 10.1530/endoabs.73.PEP11.7

132. Bergthorsdottir R, Ragnarsson O, Skrtic S, Glad CAM, Nilsson S, Ross IL, et al. Visceral Fat and Novel Biomarkers of Cardiovascular Disease in Patients With Addison's Disease: A Case-Control Study. J Clin Endocrinol Metab (2017) 102:4264-72. doi: 10.1210/jc.2017-01324

133. Bancos I, Hazeldine J, Chortis V, Hampson P, Taylor AE, Lord JM, et al. Primary Adrenal Insufficiency Is Associated With Impaired Natural Killer Cell Function: A Potential Link to Increased Mortality. Eur J Endocrinol (2017) 176:471-80. doi: 10.1530/EJE-16-0969

Conflict of Interest: AI has served as a consultant in the advisory boards for Novartis, Takeda, Recordati, and Sandoz and has received unconditional research grants from Shire, IPSEN, and Pfizer.

The remaining authors declare that the research was conducted in the absence of any commercial or financial relationships that could be construed as a potential conflict of interest.

Publisher's Note: All claims expressed in this article are solely those of the authors and do not necessarily represent those of their affiliated organizations, or those of the publisher, the editors and the reviewers. Any product that may be evaluated in this article, or claim that may be made by its manufacturer, is not guaranteed or endorsed by the publisher.

Copyright (๑) 2021 Hasenmajer, Bonaventura, Minnetti, Sada, Sbardella and Isidori. This is an open-access article distributed under the terms of the Creative Commons Attribution License (CC BY). The use, distribution or reproduction in other forums is permitted, provided the original author(s) and the copyright owner(s) are credited and that the original publication in this journal is cited, in accordance with accepted academic practice. No use, distribution or reproduction is permitted which does not comply with these terms. 